\title{
Effect of lactose-induced diarrhoea on absorption of nitrogen and fat
}

\author{
M. D. BOWIE \\ From the Department of Paediatrics and Child Health, University of Cape Town, and Red Cross War Memorial \\ Children's Hospital, Rondebosch, South Africa
}

\begin{abstract}
Bowie, M. D. (1975). Archives of Disease in Childhood, 50, 363. Effect of lactose-induced diarrhoea on absorption of nitrogen and fat. The absorption of fat and the absorption and retention of nitrogen were studied in 20 children with kwashiorkor. 13 of the 20 had lactose malabsorption and severe diarrhoea on milk feeds. Fat absorption was not affected by lactose-induced diarrhoea, but nitrogen absorption was impaired. Despite this, nitrogen retention was unaffected and it is concluded that milk and milk products should continue to be used in programmes to eliminate malnutrition.
\end{abstract}

Children with protein-energy malnutrition frequently have diarrhoea which may be severe and prolonged. The majority respond to a disaccharide-free diet with dramatic reduction in daily stool weight as the diarrhoea is due to lactose malabsorption, the result of intestinal lactase deficiency (Bowie, Brinkman, and Hansen, 1963, 1965; Bowie, Barbezat, and Hansen, 1967). There is a generalized depression of all disaccharidase enzymes but malabsorption of sucrose and maltose is less commonly a practical clinical problem (Barbezat et al., 1967). In individual cases of kwashiorkor with severe diarrhoea, lactose-free milk substitutes are of proven value in treatment.

The high incidence of lactose malabsorption in severely malnourished infants is of importance, since in most areas of the world improvement of nutrition is accomplished with milk or dried milk products. The lactose present in these nutriments may actually increase and perpetuate the diarrhoea in some children (Herbst, Sunshine, and Kretchmer, 1969). However, there is evidence that milk is generally tolerated well enough in most patients for the initiation of cure (Prinsloo et al., 1969).

The present study reports the effect of lactoseinduced diarrhoea in children with kwashiorkor on the absorption of nitrogen and fat.

\section{Material and methods}

Twenty children with protein-energy malnutrition were studied. All had the characteristic signs of kwashiorkor. They were underweight for age, oedema tous, miserable, and had hypoalbuminaemia. They were admitted to a metabolic ward and routine treatment was started. From the next day they were nursed on metabolic beds to obtain separate stool and urine collections. The patients were given full-strength fullcream milk feeds for the first 3 days, then a disaccharidefree formula containing glucose ${ }^{\star}$ (Bowie et al., 1967) for a further 4 days, and finally full-strength full-cream milk feeds for a further 4 days. The days on which the diets were changed were excluded so that there were 3 study periods of 3 days each.

The investigations in which the state of lactose absorption in malnourished children was studied have been previously reported (Bowie et al., 1967).

Nitrogen balance and absorption was performed during the 3-day periods on milk, disaccharide-free diet, and milk feeds. Stools were collected and weighed and proportional aliquots of the stool specimens for 24 hours were taken. At the end of the 3-day period these were pooled, thoroughly mixed, and analysed. Food intake was measured by weighing all bottles before and after feeds. Aliquots of each day's feed were analysed for nitrogen content. Urine was collected under toluene and a 24-hour specimen was frozen. An aliquot of the pooled specimen for 3 days was analysed.

\begin{tabular}{lr}
\hline *Casilan, Glaxo & \\
Protein & $38 \mathbf{g}$ \\
Glucose & $32 \mathbf{g}$ \\
Fat (thick cream) & $25 \mathbf{g}$ \\
Special salt & $5 \mathrm{~g}$ \\
Water to & $800 \mathrm{ml}$ \\
Special salt: & $10 \%$ \\
Calcium carbonate & $33 \%$ \\
Dipotassium hydrophosphate & $7 \%$ \\
Dicalcium phosphate & $40 \%$ \\
Sodium chloride & $10 \%$ \\
Magnesium sulphate &
\end{tabular}


Nitrogen content of the aliquots of feeds, stool, and urine was measured by a micro-Kjeldahl technique done in duplicate (Perrin, 1953).

Fat balance and absorption was performed at the same time as nitrogen balance and in a similar manner. Aliquots were taken from each day's diet and the total intake determined as in nitrogen balance. The stool specimens analysed were those collected for nitrogen content. Fat content of the diet and stools was determined by the method of van de Kamer, ten Bokkel Huinink, and Weyers (1949).

\section{Results}

The division of these children into 'nonabsorbers' and 'absorbers' of lactose has previously been described (Bowie et al., 1967). 13 of the children showed marked variations of stool weight, stool lactic acid content, and stool sugar on being changed from milk to disaccharide-free diet and back again. These children had severe diarrhoea while gn milk. Lactose malabsorption in this group (the nonabsorbers) was confirmed by abnormal lactose tolerance tests and low or absent small intestine mucosal lactase enzyme assay. 7 children (the absorbers) showed little variation in stool weight and lactic acid content, and lactose tolerance tests showed satisfactory absorption. Disaccharidase enzyme activity was normal.

Nitrogen absorption. In both the absorbers and nonabsorbers there were significant changes in nitrogen absorption (Table I). The absorbers showed a better percentage nitrogen absorption on the disaccharide-free diet as compared with the initial period on milk $(P<0.02)$. There was no significant deterioration when these children were put back on milk feeds. In the nonabsorbers there was a significant improvement when changing the diets from milk to disaccharide-free formula $(P<0.02)$ and deterioration $(P<0.001)$ on the reintroduction of milk.

Comparison of the absorbers and nonabsorbers showed no significant difference in percentage nitrogen absorption during the first period on milk, nor on the disaccharide-free diet. During the second period on milk, nitrogen absorption was better in the absorbers $(P<0.01)$.

Stool weight and nitrogen absorption showed an inverse correlation $(P<0.0005)$ during all 3 diet periods. Mean stool nitrogen in $\mathrm{g} / 24 \mathrm{~h}$ was highest in the nonabsorbers while they were on milk (Table I).

Nitrogen retention. Bcth absorbers and nonabsorbers had positive nitrogen balances from the start of feeding (Table I). There was no significant difference in mean nitrogen retention between absorbers and nonabsorbers in any diet period. Nitrogen retention progressively dropped with continued feeding.

Fat absorption. There was no significant change in the absorption coefficient of fat in either the nonabsorbers or absorbers with dietary changes (Table II). No significant difference was found

TABLE I

Mean nitrogen absorption and retention

\begin{tabular}{|c|c|c|c|c|}
\hline Diet & Lactose absorption & $\begin{array}{c}\text { Nitrogen absorption } \\
(\%)\end{array}$ & $\begin{array}{c}\text { Stool nitrogen } \\
(\mathrm{g} / 24 \mathrm{~h})\end{array}$ & $\begin{array}{c}\mathrm{N}_{2} \text { retention } \\
\left(\mathrm{mg} \mathrm{N} \mathrm{N}_{2} / \mathbf{k g} \text { per } \mathrm{d}\right)\end{array}$ \\
\hline $\begin{array}{l}\text { Milk } \\
\text { Disaccharide-free diet } \\
\text { Milk }\end{array}$ & $\begin{array}{l}\text { Absorbers } \\
\text { Nonabsorbers } \\
\text { Absorbers } \\
\text { Nonabsorbers } \\
\text { Absorbers } \\
\text { Nonabsorbers }\end{array}$ & $\begin{array}{l}84 \\
76 \\
92 \\
88 \\
88 \\
80\end{array}$ & $\begin{array}{l}0 \cdot 73 \\
1 \cdot 14 \\
0 \cdot 54 \\
0 \cdot 78 \\
0 \cdot 74 \\
1 \cdot 38\end{array}$ & $\begin{array}{l}+278 \\
+226 \\
+253 \\
+235 \\
+171 \\
+169\end{array}$ \\
\hline
\end{tabular}

TABLE II

Mean fat absorption

\begin{tabular}{|c|c|c|c|}
\hline Diet & Lactose absorption & Fat absorption (\%) & Stool fat $(g / 24 h)$ \\
\hline $\begin{array}{l}\text { Milk } \\
\text { Disaccharide-free diet } \\
\text { Milk }\end{array}$ & $\begin{array}{l}\text { Absorbers } \\
\text { Nonabsorbers } \\
\text { Absorbers } \\
\text { Nonabsorbers } \\
\text { Absorbers } \\
\text { Nonabsorbers }\end{array}$ & $\begin{array}{l}82 \\
68 \\
88 \\
76 \\
86 \\
80\end{array}$ & $\begin{array}{r}8 \cdot 5 \\
15 \cdot 7 \\
7 \cdot 3 \\
12 \cdot 1 \\
10 \cdot 3 \\
15 \cdot 7\end{array}$ \\
\hline
\end{tabular}


between the 2 groups during any dietary period. The coefficient of fat absorption and stool fat content generally showed a greater degree of steatorrhoea in the nonabsorbers than the absorbers, but this was not statistically significant.

There was no correlation between stool weight and fat absorption. A moderate degree of steatorrhoea persisted throughout. The stool fat content was lower in the disaccharide-free period in both groups but this diet had a lower fat content than the milk.

\section{Discussion}

The diarrhoea of lactose malabsorption is mainly due to the osmotic effect of the unabsorbed sugar in the small and large bowel (Haemmerli et al., 1965). Water resorption is obviously diminished and it seemed possible that this osmotic effect in the small intestine might impair the absorption of other nutrients. The fact that kwashiorkor can usually be cured with milk did suggest that this effect might not be of great practical significance.

Lactose-induced diarrhoea has been shown to have no effect on xylose absorption. Some evidence of a delay in absorption was found but this appeared to be related to the intestinal damage in kwashiorkor and occurred in children both with and without lactose intolerance (Bowie et al., 1967).

Nitrogen absorption in this series was affected by the lactose-induced diarrhoea and the more severe the diarrhoea, the poorer the nitrogen absorption. Both absorbers and nonabsorbers initially had impaired indices of apparent nitrogen absorption but in the absorbers this rapidly rose to normal levels and remained there. In the nonabsorbers nitrogen absorption was normal when the diarrhoea was controlled on a lactose-free feed but with the reintroduction of milk feeds the recurrence of diarrhoea was accompanied by a significant drop in apparent nitrogen absorption.

Mean stool nitrogen during the 2 periods of lactose-induced diarrhoea was $1.14 \mathrm{~g}$ and 1.38 $\mathrm{g} / \mathrm{d}$. Normal faecal nitrogen for children of this age is usually less than $1 \mathrm{~g} / \mathrm{d}$ (Shmerling, Forrer, and Prader, 1970). The endogenous contribution of protein to faecal nitrogen is large and dietary protein is usually diluted by a factor of 3 in the alimentary tract by proteins from secretions and shed cells. In normal circumstances most of these proteins are digested and absorbed. Faecal nitrogen estimations are considered to be an index of protein digestion and absorption. The poorer index of apparent nitrogen absorption and high faecal nitrogen during periods of lactose-induced diar- rhoea therefore suggests some impairment of protein digestion and absorption.

The significance of this poorer nitrogen absorption becomes apparent when one considers nitrogen retention. The nonabsorbers with diarrhoea and impaired nitrogen absorption simply retained more of the nitrogen they absorbed. Whether diarrhoea was present or not, nitrogen retention was high, gradually dropping as protein repletion occurred.

Fat absorption was not affected by the diarrhoea. A moderate degree of steatorrhoea persisted throughout in both groups. The lower stool fat content on the disaccharide-free diet can be accounted for by the lower fat content of that diet. The coefficient of fat absorption was generally poorer and stool fat content higher in the nonabsorbers than the absorbers, and though this is not statistically significant it may suggest a greater degree of intestinal mucosal and pancreatic dysfunction in these patients.

It appears that the diarrhoea induced by lactose malabsorption in malnourished children does effect absorption of nitrogen but does not effect protein repletion. Despite contrary advice (Dahlqvist and Lindquist, 1971), state and international agencies should continue to advocate the use of milk or milk products in programmes to eliminate malnutrition. It is usually the cheapest and often the only widely available source of protein. It will effectively prevent protein-energy malnutrition in the preschool child. In established cases many can be cured by the use of milk even if diarrhoea is induced. With protein refeeding many regain their ability to tolerate lactose (James, 1971). It is only in a minority of patients that diarrhoea is unacceptably severe, and in order to manage the problems of water and electrolyte loss a lactosefree formula will be required for a variable period of time.

Financial support was received from NIHPHS (U.S.A.) grant No. A3995 and the Council for Scientific and Industrial Research, South Africa.

\section{REFERENCES}

Barbezat, G. O., Bowie, M. D., Kaschula, R. O. C., and Hansen, J. D. L. (1967). Studies on the small intestinal mucosa of children with protein-calorie malnutrition. South African Medical fournal, 41, 1031.

Bowie, M. D., Barbezat, G. O., and Hansen, J. D. L. (1967). Carbohydrate absorption in malnourished children. American fournal of Clinical Nutrition, 20, 89.

Bowie, M. D., Brinkman, G. L., and Hansen, J. D. L. (1963). Diarrhoea in protein-calorie malnutrition. Lancet, $2,550$.

Bowie, M. D., Brinkman, G. L., and Hansen, J. D. L. (1965), Acquired disaccharide intolerance in malnutrition. fournal of Pediatrics, 66, 1083.

Dahlqvist, A., and Lindquist, B. (1971). Lactose intolerance and protein malnutrition. Acta Paediatrica Scandinavia, 60, 488. 
Haemmerli, U. P., Kistler, H., Ammann, R., Marthaler, T, Semenza, G., Auricchio, S., and Prader, A. (1965). Acquired milk intolerance in the adult caused by lactose malabsorption due to a selective deficiency of intestinal lactase activity. American fournal of Medicine, 38, 7.

Herbst, J. J., Sunshine, P., and Kretchmer, N. (1969). Intestinal malabsorption in infancy and childhood. Advances in Pediatrics, Vol. 16, p. 11. Ed. by I. Schulman. Year Book Medical Publishers, Chicago, Ill.

James, W. P. T. (1971). Jejunal disaccharidase activities in children with maramus and with kwashiorkor. Response to treatment. Archives of Disease in Childhood, 46, 218.

Perrin, C. H. (1953). Rapid modified procedure for determination of Kjeldahl nitrogen. Analytical Chemistry, 25, 968.

Prinsloo, J. G., Wittmann, W., Pretorius, P. J., Kruger, H., and Fellingham, S. A. (1969). Effect of different sugars on diarrhoea of acute kwashiorkor. Archives of Disease in Childhood, 44, 593.

Shmerling, D. H., Forrer, J. C. W., and Prader, A. (1970). Fecal fat and nitrogen in healthy children and in children with malabsorption or maldigestion. Pediatrics, 46, 690.

van de Kamer, J. H., ten Bokkel Huinink, H., and Weyers, H. A (1949). Rapid method for the determination of fat in feces. fournal of Biological Chemistry, 177, 347.

Correspondence to Dr. M. D. Bowie, Institute of Child Health, Red Cross War Memorial Children's Hospital, Rondebosch 7700, Cape, South Africa. 